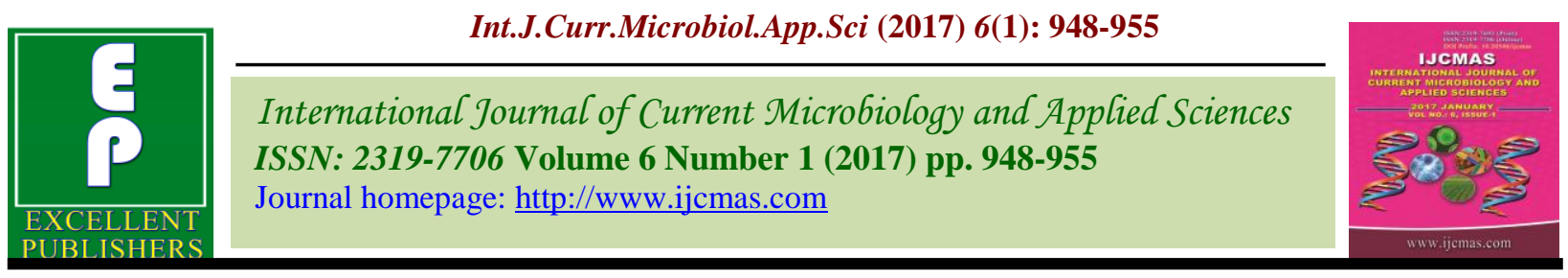

Original Research Article

http://dx.doi.org/10.20546/ijcmas.2017.601.112

\title{
Evaluation of Safety of Street Foods in Delhi Using a HACCP Approach
}

\author{
Niharika Sachdev* and Pulkit Mathur \\ Department of Food and Nutrition, Lady Irwin College, University of Delhi, Delhi, India \\ *Corresponding author
}

\begin{tabular}{|l|}
\hline K ey w o r d s \\
$\begin{array}{l}\text { Street foods, } \\
\text { microbiological } \\
\text { quality, } \\
\text { food safety, } \\
\text { HACCP. }\end{array}$ \\
\hline Article Info \\
\hline $\begin{array}{l}\text { Accepted: } \\
\text { 28 December } 2016 \\
\text { Available Online: } \\
\text { 10 January } 2017\end{array}$ \\
\hline
\end{tabular}

A B S T R A C T

Street foods are an important part of urban diets for the low and middle income group as they are readily available and low cost. Safety of these street vended foods is of vital importance from the public health point of view in developing countries like India. A total of 148 street food stalls in fives zones of Delhi were surveyed using an observation checklist to document available foods, physical condition of vending location, food preparation and handling practices and personal hygiene of street food vendors. Food items most likely to be microbiologically unsafe were identified. A total of 25 samples of kulfi and 20 vegetable momos with chutney were analysed for total plate count, coliform count, yeast and mould count and staphylococcal count. Samples were tested for faecal coliform and E.coli. HACCP plans were drawn out forkulfi and vegetable momos to identify critical control points in their preparation and suggest control measures. A wide variety of snacks, meals, desserts and beverages were being sold on the streets of Delhi. About $80 \%$ of the vendors indulged in risky food handling practices like handling food with bare hands, $95 \%$ used the same duster to wipe hands and utensils, $70 \%$ used unclean material for wiping hands and $31 \%$ did not keep their foodstuffs covered. About $14 \%$ of vendors were not serving hot food hot while $36 \%$ of the vendors were not serving cold foods cold. Microbiological analysis revealed that $22(88 \%)$ samples of kulfi out of 25 were not fit for human consumption as per national standards. Only 9 momos samples out of 20 were found to be fit for consumption. All 20 samples of chutney were unfit for human consumption. The HACCP results were used to make suggestions which need investment more in terms of effort than cost for vendors in unorganised sectors. Besides using clean equipment and work surfaces, it is advised to reheat the kulfi mixture before freezing. While in case of vegetable momos, sautéing the momo filling can reduce contamination.

\section{Introduction}

Street foods are a reality in all countries of world. More than 3 million Indians are directly involved in this informal sector of street food vending (Kurunthachalam, 2013). Eating out in Delhi is very common among all age groups.
These foods are appreciated for characteristic flavour, variety and availability at low cost especially at crowded places such as local markets, tourist places, work place, railway stations, bus terminals, school and hospital premises (Das et al., 2012). 
There are a number of physical as well as chemical hazards associated with road side foods. Many times street food vendors operate in congested areas of the city where foods, food stalls and vendors are exposed to dust, grit, air borne chemicals, exhaust gases and burning fumes. Vending sites lack waste disposal and waste water discharge facilities (Proietti, Frazzoli and Mantovani, 2014). Street foods industry contributes to a significant part of total food intake of millions of people in India. However this informal sector is unregulated and poses a health risk. People who eat street foods are at the risk of food poisoning. Most common risk factors for contamination of foods are storage of foods at inappropriate temperature conditions, poor personal hygiene and poor handling. For street foods to be wholesome and safethere is a need to identify important control check points and control measures at each stage of street food preparation process chain, which the vendor can easily implement considering his limited resources. Hence, theobjective of this study wasto identify the types of street foods available in Delhi and to assess hygiene and handling practices followed by street vendors. The microbiological quality of selected high risk street foods - kulfi (a frozen dairy dessert) and vegetable momos (dumplings) was assessed. A HACCP (Hazard Analysis Critical Control Point) study was used to identify critical control points during preparation of these foods.

\section{Material and Methods}

Delhi is divided into 9 zones according to Department of Registrar Co-operative Society, Government of National Capital Territory of Delhi, India. Out of these, 5 zones were selected for the study and pilot survey was conducted to identify main markets, popular tourist places, office complexes and hospitals in each zone where people as well as street food vendors congregate in large numbers. A pre-tested observation checklist (based on Confederation of Indian Industry-14 Point on food safety for street food vendors)was used to gather information like type of vending unit (mobile / kiosk), number of vendors at the stall, and parameters to describe the food preparation process and handling practices at vending locations like cooking and holding practices, nature of food served, condition of vending location, physical facilities, water source, waste disposal, preparation equipment, serving utensils, packaging material, food storage, cooking fuel used, etc.

\section{Microbiological analysis of selected food items}

Based on the observation study, two high risk food items were identified and microbiological analysis was carried out. The two food items -vegetable momos (a steamed snack preparation) and kulfi (a frozen dessert preparation) were analysed for Standard Plate count, Coliforms count, Yeast and mould count andStaphylococcal count using standard Bureau of Indian Standards (BIS) procedures.The presence of pathogenic micro-organisms like faecal coliform, Escherichia coli was also checked.Food samples were collected in sterile bags, refrigerated and analysed within 24 hours of collection.

A total of 25 samples of stick kulfi and 20 samples of momos (covering, filling and chutney analysed separately) were tested.For the HACCP study, several street food vendors were approached and objectives of the study explained to them. Two vendors gave informed consent to participate in the HACCP study and allowed the researcher to study the process of preparation of momos and kulfi. 


\section{Results and Discussion}

A total of 148 vendors were observed during the survey using an observation checklist. Salient findings of the survey are discussed under different subheads.

\section{Type of vending system}

About $53 \%$ of the vendors operated out of kiosk units as compared to $47 \%$ who had mobile units (pushcarts). Majority (97\%) of the stalls were operated by male vendors. Few children (at $11 \%$ stalls) were employed in vending of food.

\section{Profile of street foods}

Almost half of the total stalls surveyed were selling more than one type of food item. Mostly vegetarian foods were available. A range of foods from raw to processed were available on streets of Delhi. Among the snack foods sold, momos (dumplings), golgappas, bhelpuri, ram laddoo (spicy snackitems)were more popular. Chole kulche, Chole bhature (chick peas with Indian breads), vegetarian chaap(cutlets)with rumali roti, paranthe(types of Indian breads), fermented foods such as Sambhar vada, idli, dosa(preparations of South Indian cuisine made of rice and pulse), rice with rajma and kadhi, chicken biryani were some of the popular meals sold on Delhi's streets. Stick kulfi and rabri faluda(Indian desserts) are more common on street. Chuski(snow balls with syrup), Jalebi(fried preparation dipped in sugar syrup), and chocolate coated puddings, pies, cakes and brownies are other popular sweet items.

\section{Processing of street food}

In totality, precooked foods were sold more than the food being cooked on site (31\%). About $14 \%$ of vendors were not serving hot food hot while $36 \%$ of the vendors were not serving cold foods cold. Serving food at the right temperature is important not just from taste point of view but also from food safety point of view. Keeping the foods hot or at a low temperature prevents growth of microorganisms.

\section{Physical condition of vending locations}

Large number of food stalls in west and south zone operated in crowded places. Most $(65 \%)$ of the vending stalls hada water source (municipal tap) in the vicinity. About $59 \%$ of the vendors were storing water in different types of containers. About $78 \%$ of those who stored water used plastic containers for the purpose. Stored water has to be used with care so that it doesn't become contaminated. Almost half $(43 \%)$ of the vendors had a garbage pile next to their stall. Filth in and around vending location attracts pests and increases risk of food contamination.

\section{Food preparation and handling practices}

Use of clean disposables for serving food is preferred. Most (90\%) vendors used clean utensils for food service. About (78\%) vendors offered take away services. Different types of material such as aluminium (foil, laminated pouches, boxes), brown paper, newspaper, plastic (polythene bags, tubs, glasses, cups) are used for packing of food. Some of these materials are unsafe for use as they leach chemicals into the foods kept in them. About $80 \%$ of the vendors indulged in risky food handling practices like handling food with bare hands, $95 \%$ used the same duster to wipe hands and utensils, $70 \%$ used unclean material for wiping hands and 31\% did not keep their foodstuffs covered. The vendor does not have to invest a lot of time or money in observing basic food safety practices like using separate and clean dusters for hands and utensils or keeping the food covered. Awareness and a sense of 
responsibility needs to be instilled in food handlers through effective training programs.

\section{Personal hygienic practices}

Personal hygiene practices were poor in north and south zone compared to other zones as less number of vendors in these zones had short hair and short and clean nails.Almost $80 \%$ of the street food vendors were wearing clean clothes during food vending activity. But none of them had aprons.

\section{Microbiological analysis of the selected food items}

On the basis of the vendor survey, and the time and resources available, two high risk foods were identified - kulfi andmomos. Momos $(\mathrm{n}=20)$ and kulfi $(\mathrm{n}=25)$ samples collected from each zone were analysed. Table 1 gives the results of the microbiological analysis of the two foods. Twenty two (88\%) samples of kulfi out of 25 were not fit for human consumption as per criteria given by Food Safety and Standards Authority of India (FSSAI, 2011) for microbiological safety of ice creams and frozen desserts. Another study done in Chandigarh had reported total bacterial counts in the range of $2 \times 10^{1}$ to $5.2 \times 10^{11}$ cfu per $\mathrm{ml}$ for kulfi (Vaishnavi et al., 2002).Only $16 \%$ samples of kulfi obtained from different sources in Bikaner city were of satisfactory quality considering SPC as a criterion, whereas coliform count revealed that $100 \%$ samples were of unsatisfactory category. E. coli and Staphylococcal analysis showed that none of the samples were free from pathogens (Choudhary et al., 2008).

Microbiological analysis of momos samples was done in two parts as shown in Table 1.Out of total 20 casings of the dumplings, 11 were fit for consumption and 9 were unfit for consumption. Out of 20 fillings of the dumpling samples, 13 were fit for consumption and 7 were unfit for consumption. On the whole 9 casings and 9 filling samples i.e. 9 dumpling samples were found to be fit for consumption. Both casing and filling were contaminated to the same extent indicating problem of overall lack of hygiene in preparation and handling. None of the chutney samples were found to be fit for human consumption.

\section{HACCP Analysis of Kulfi and Momos}

In HACCP analysis of vegetable momos (Table 2), results showed importance of personal hygiene in food preparation. Contaminated raw material, unwashed hands and equipment are possible sources of contamination. It is suggested that vegetables be sautéed before filling into momo casing, handling of ingredients with bare hands should be avoided as much as possible, food preparation should not be done on floor if possible. However if it cannot be helped then footwear should not be allowed in the cooking area and the whole floor area should be sanitized before food preparation begins. Hand washing was shown to reduce contamination levels of the hands of the vendor handling the dough. The study also showed that steaming for $10 \mathrm{~min}$ is a very mild heat treatment and although it killed the pathogens, it did not destroy all the bacteria and yeasts and moulds.

The HACCP results for kulfi(Table 3) revealed that use of contaminated raw materials, poor environmental conditions and use of unsanitized equipment, utensils, wooden sticks recontaminates the final product. Heat treatment given to milk during the preparation almost destroyed the pathogens present. Addition of khoa(low moisture dairy product made by thickening milk by open pan boiling) to the boiled milk introduced contamination. However while concentrating the mixture to about half of its volume, it was subjected to high temperature 
for a long period of time which ensured that pathogens were destroyed.

It was seen that recontamination took place at the stage of transferring the prepared mixture into steel cans which were not clean. After transferring to steel cans, the mixture was kept uncovered to cool and was exposed to flies and insects in the environment. Final cooled mixture was found to be contaminated with pathogens. Vendor was found to usean unclean glass with a long handle for filling of cones with the mixture. Wooden sticks inserted into the cones were kept unhygienically in the vending cart and also contributed to the contamination of the final product.

Use of thoroughly sanitized utensils, use of sterile sticks or hygienically packed sticks is necessary to prevent contamination of the finished product. Also if mixture has not been held at $4^{\circ} \mathrm{C}$ or mixture has been stored for an undesirably long period, it is recommended to heat the mixture once more before freezing. Mixture for the dessert preparation is usually prepared in bulk and then sold to different vendors who freeze it in cones in their vending carts.

In conclusion, awareness, education and training of food vendors on importance of following basic principles of hygiene and sanitation are vital. The following suggestions are made which need investment more in terms of effort than cost:

First and foremost, the vendors need to designate a clear area for the purpose of food preparation. If due to lack of space they use the area for other activities, the area needs to be cleared, cleaned and sanitized before food preparation begins.

Using separate dusters for separate operations like wiping hands, wiping equipment and work surfaces is important to prevent cross contamination. Avoid spillage at work place and in case of spillage, it should be cleared up immediately.

Maintaining hot foods at high temperature or reheating before service can reduce microbial load. Momos in this study needed to be heated longer or the filling needed sautéing to reduce microbial load.

Table.1 Microbiological Analysis of Kulfi and Vegetable Momo Samples

\begin{tabular}{|l|l|l|l|l|l|}
\hline $\begin{array}{l}\text { Microbiological } \\
\text { Test }\end{array}$ & Sample & $\begin{array}{l}\text { Kulfi } \\
\text { (N=25) }\end{array}$ & $\begin{array}{l}\text { Momo } \\
\text { coverings } \\
(\mathbf{N = 2 0})\end{array}$ & $\begin{array}{l}\text { Momo } \\
\text { fillings } \\
(\mathbf{N = 2 0})\end{array}$ & $\begin{array}{l}\text { Momo } \\
\text { chutney } \\
\text { (N=20) }\end{array}$ \\
\hline \multirow{2}{*}{ TPC Count } & Mean & $2.2 \times 10^{6}$ & $6.2 \times 10^{6}$ & $6.2 \times 10^{4}$ & $2.8 \times 10^{5}$ \\
\cline { 2 - 6 } & Range & ND to TNTC & ND to $6.1 \times 10^{6}$ & ND to $5.4 \times 10^{4}$ & $\begin{array}{l}6.3 \times 10^{3} \text { to } \\
\text { TNTC }\end{array}$ \\
\hline \multirow{2}{*}{ Coliform Count } & Mean & $2.6 \times 10^{5}$ & $7.8 \times 10^{5}$ & $3.1 \times 10^{4}$ & $1.8 \times 10^{5}$ \\
\cline { 2 - 6 } & Range & $\begin{array}{l}\text { ND to } \\
1.5 \times 10^{5}\end{array}$ & ND to $7.7 \times 10^{5}$ & ND to TNTC & ND to TNTC \\
\hline \multirow{2}{*}{ Yeast and Mold Count } & Mean & $5.8 \times 10^{5}$ & $3.8 \times 10^{4}$ & $2.1 \times 10^{4}$ & $2.9 \times 10^{5}$ \\
\cline { 2 - 6 } & Range & ND to $2.2 \times 10^{5}$ & ND to $1.2 \times 10^{4}$ & ND to $1.2 \times 10^{4}$ & ND to TNTC \\
\hline \multirow{3}{*}{ S aureus Count } & Mean & $7.9 \times 10^{4}$ & $7.5 \times 10^{3}$ & $1.9 \times 10^{4}$ & $3.4 \times 10^{4}$ \\
\cline { 2 - 5 } & Range & ND to $4 \times 10^{4}$ & ND to $5.5 \times 10^{3}$ & ND to $4.2 \times 10^{3}$ & ND to TNTC \\
\hline
\end{tabular}

All counts are in cfu/g. Mean values are the averages obtained from plates that give countable results.

$N D=<1 \times 10^{l} \mathrm{cfu} / \mathrm{g}$ and $n=$ number of food samples tested for a particular zone

$N=$ total number of sample 


\begin{tabular}{|c|c|c|c|c|c|c|c|c|}
\hline \multicolumn{9}{|c|}{ Table 2. HACCP Analysis for VegetableMomos } \\
\hline $\begin{array}{l}\text { Process } \\
\text { step }\end{array}$ & Sample Analysed & $\begin{array}{l}\text { Total Plate } \\
\text { Count } \\
\text { (cfu/g) }\end{array}$ & $\begin{array}{l}\text { Coliform } \\
\text { count } \\
(\text { cfu/g) }\end{array}$ & E. coli & $\begin{array}{l}\text { Yeast \& } \\
\text { Mould } \\
\text { Count } \\
(\text { cfu/g) }\end{array}$ & S.aureus & Remarks & Action Points for Vendor \\
\hline \multirow{3}{*}{$\begin{array}{l}\text { Receiving } \\
\text { of raw } \\
\text { materials }\end{array}$} & Refined wheat flour & $1.3 \times 10^{4}$ & $2.6 \times 10^{2}$ & Present & $5.5 \times 10^{3}$ & ND & Contaminated & \multirow{3}{*}{$\begin{array}{l}\text { *Reject insect infested flour. } \\
\text { Sieve before use. } \\
\text { *Washing of vegetables with } \\
\text { potable water before storing } \\
\text { and use. } \\
\text { *Reject adulterated spices and } \\
\text { use good quality packaged } \\
\text { spices }\end{array}$} \\
\hline & Spices & TNTC & $1 \times 10^{4}$ & Present & ND & Absent & Contaminated & \\
\hline & $\begin{array}{l}\text { Raw vegetables mixed with } \\
\text { spices }\end{array}$ & TNTC & TNTC & Present & $2.3 \times 10^{4}$ & Present & Contaminated & \\
\hline \multirow[t]{3}{*}{$\begin{array}{l}\text { Dough } \\
\text { Making }\end{array}$} & $\begin{array}{l}\text { Initial swabs of the first } \\
\text { vendor who was making } \\
\text { dough }\end{array}$ & Spreader & $4.9 \times 10^{2}$ & Present & ND & Present & Hands were contaminated & \multirow[t]{3}{*}{$\begin{array}{l}\text { * water to be boiled before use } \\
\text { *hands and utensils to be } \\
\text { washed before use }\end{array}$} \\
\hline & $\begin{array}{l}\text { Swab of kadhai for dough } \\
\text { making }\end{array}$ & $1.5 \times 10^{5}$ & TNTC & Present & $3.4 \times 10^{2}$ & Present & $\begin{array}{l}\text { Dirty contaminated } \\
\text { Utensil }\end{array}$ & \\
\hline & Dough prepared & TNTC & TNTC & Present & $6.5 \times 10^{3}$ & Present & Contaminated & \\
\hline \multirow[t]{2}{*}{$\begin{array}{l}\text { Grating } \\
\text { vegetable }\end{array}$} & $\begin{array}{l}\text { Hand swabs of second } \\
\text { vendor before cutting and } \\
\text { chopping of vegetables }\end{array}$ & $3.1 \times 10^{4}$ & $1 \times 10^{4}$ & ND & $8.8 \times 10^{3}$ & Present & Contributes to contamination & \multirow{2}{*}{$\begin{array}{l}\text { *Cleaning of equipment with } \\
\text { hot water. } \\
\text { *Washing hands before any } \\
\text { operation involving touching } \\
\text { ingredients }\end{array}$} \\
\hline & Swabs of grater & Spreader & $2.2 \times 10^{4}$ & Present & $5.4 \times 10^{2}$ & Present & Contaminated as not washed properly & \\
\hline \multirow{2}{*}{$\begin{array}{l}\text { Rolling } \\
\text { into } \\
\text { dough } \\
\text { balls }\end{array}$} & $\begin{array}{l}\text { Swab of Rolling pin (metal } \\
\text { rod) }\end{array}$ & Spreader & ND & Absent & ND & Present & $\begin{array}{l}\text { Slightly contaminated. Not washed } \\
\text { properly }\end{array}$ & \multirow[t]{2}{*}{$\begin{array}{l}\text { Thorough cleaning of } \\
\text { equipment before use }\end{array}$} \\
\hline & Swab of Chakla & $2.4 \times 10^{4}$ & $8.6 \times 10^{2}$ & Present & ND & Absent & Not washed properly & \\
\hline Steaming & Steamed momo & $1.6 \times 10^{4}$ & ND & Absent & $5.4 \times 10^{2}$ & ND & $\begin{array}{l}\text { Reduced microbial load, pathogens } \\
\text { destroyed but some bacteria, yeast and } \\
\text { molds still present. }\end{array}$ & $\begin{array}{l}\text { Heat the product again for } \\
\text { adequate time }\end{array}$ \\
\hline
\end{tabular}


Table.3 HACCP Analysis for kulfi

\begin{tabular}{|c|c|c|c|c|c|c|c|c|}
\hline Process step & Sample Analysed & $\begin{array}{l}\text { Total } \\
\text { Plate } \\
\text { Count } \\
(\text { cfu/g) }\end{array}$ & $\begin{array}{l}\text { Coliform } \\
\text { count } \\
(\text { cfu/g) }\end{array}$ & E. coli & $\begin{array}{l}\text { Yeast } \\
\text { and } \\
\text { Mould } \\
\text { Count } \\
\text { (cfu/g) }\end{array}$ & $\begin{array}{l}\text { S. } \\
\text { aureus }\end{array}$ & Remarks & $\begin{array}{l}\text { Action Points for } \\
\text { Vendor }\end{array}$ \\
\hline \multirow[t]{5}{*}{$\begin{array}{l}\text { Receiving of raw } \\
\text { materials }\end{array}$} & Raw milk & TNTC & TNTC & Present & $\begin{array}{l}3.1 \\
\times 10^{2}\end{array}$ & Present & $\begin{array}{l}\text { Milk is not of good } \\
\text { quality }\end{array}$ & \multirow{5}{*}{$\begin{array}{l}\text { Accept only fresh } \\
\text { milk and khoa } \\
\text { from reliable } \\
\text { supplier. If in } \\
\text { doubt reject. } \\
\text { Store at low } \\
\text { temperatures } \\
\text { if preparation not } \\
\text { immediate }\end{array}$} \\
\hline & $\begin{array}{l}\text { Packaged } \\
\text { Powder }\end{array}$ & ND & ND & Absent & ND & Absent & $\begin{array}{l}\text { Custard Powder is } \\
\text { of good quality }\end{array}$ & \\
\hline & Khoa & TNTC & $6.2 \times 10^{2}$ & Present & $1 \times 10^{3}$ & Present & $\begin{array}{l}\text { Khoa is not of good } \\
\text { quality }\end{array}$ & \\
\hline & Sugar & ND & $\mathrm{ND}$ & Absent & $8.3 \times 10^{2}$ & Absent & Acceptable & \\
\hline & Nuts & TNTC & ND & Absent & $2.9 \times 10^{3}$ & Present & Contaminated & \\
\hline \multirow[t]{3}{*}{ Boiling of milk } & $\begin{array}{l}\text { Swab of patila(utensil } \\
\text { used to boil) }\end{array}$ & $1.9 \times 10^{4}$ & ND & Present & ND & Present & Contaminated & \multirow{3}{*}{$\begin{array}{l}\text { Wash utensils } \\
\text { withpotable water } \\
\text { before use }\end{array}$} \\
\hline & $\begin{array}{l}\text { Swab of } \\
\text { Khurpa(utensil used to } \\
\text { stir) }\end{array}$ & $8.8 \times 10^{3}$ & ND & Present & ND & Present & Contaminated & \\
\hline & Boiled milk & ND & ND & Absent & ND & Absent & $\begin{array}{l}\text { Heating destroys } \\
\text { Pathogens }\end{array}$ & \\
\hline \multirow{2}{*}{$\begin{array}{l}\text { Addition of khoa, } \\
\text { nuts and sugar }\end{array}$} & $\begin{array}{l}\text { Initial Swab of hands } \\
\text { of First vendor who } \\
\text { had washed hands }\end{array}$ & $1.5 \times 10^{3}$ & ND & Absent & ND & Absent & $\begin{array}{l}\text { Hands were fairly } \\
\text { clean }\end{array}$ & \multirow{2}{*}{$\begin{array}{l}\text { Cleaning hands } \\
\text { properly ensures } \\
\text { reduction in } \\
\text { contamination. } \\
\text { Avoid touching } \\
\text { surfaces which can } \\
\text { contaminate the } \\
\text { hands again. }\end{array}$} \\
\hline & $\begin{array}{l}\text { Swab of washed hands } \\
\text { of Second vendor } \\
\text { before Khoa and sugar } \\
\text { was added. }\end{array}$ & $2.42 \times 10^{3}$ & ND & Absent & ND & Absent & $\begin{array}{l}\text { Hands fairly were } \\
\text { clean }\end{array}$ & \\
\hline
\end{tabular}


Maintaining cold foods at cool temperature but avoiding direct contact with ice. Kulfi containers need to be sealed properly to prevent ice mixture from entering cones.

Cooling of cooked kulfi mixture needs to be done in a sanitary environment and vendor can take simple precautions like cleaning the utensils, cones etc thoroughly. Sticks should be washed with hot water before use. Also the mixture needs to be kept covered at all times to avoid physical hazards. Food and water should be kept covered. Fly mesh racks can be used. Wood shaving, waste paper can be burnt or Agarbatti or dhoop(locally available incense sticks) can be used to repel flies. Vending carts/shacks should be cleaned and covered.

If the vendor has stored cooked foods at inappropriate temperatures for long period of time (i.e. more than 2 hours at ambient temperature), he should not hesitate to reheat the food before service in case of hot foods like momos. Vendors purchasing cooked kulfi mixture should as a precautionary measure reheat before freezing.

Food vendors need to be sensitized to food safety issues. The link between unsafe food and loss of business needs to be driven home for them to feel motivated enough to change how they have been operating for years. More HACCP studies are needed for other types of foods in order to identify specific control points which then need to be communicated to street vendors.

\section{How to cite this article:}

Niharika Sachdev and Pulkit Mathur. 2017. Evaluation of Safety of Street Foods in Delhi Using a HACCP Approach. Int.J.Curr.Microbiol.App.Sci. 6(1): 948-955.

doi: http://dx.doi.org/10.20546/ijcmas.2017.601.112

\section{References}

Choudhary VK, Purohit SK, Singh PK, Bhatt L. Bacteriological quality of matka kulfi an indigenous milk product and its public health significance. Veterinary Practitioner 2008; 9(1):57-58

CII-14 Points Check on Food Safety for Street Vended Food. 2008.Version 1.0. Internet: www.cii-iq.in

Das M, Rath CC, Mohapatra UB. Bacteriology of a most popular street food (Panipuri)and inhibitory effect of essential oils on bacterial growth. Food SciTechnol2012; 49(5):564-571.DOI 10.1007/s13197-010-0202-2

FSSAI.Food Safety and Standards (Food products Standards and Food Additives) Regulations. 2011. Appendix B

Kurunthachalam SK.Possible Adverse Implications of Chemical Migration from Food Pack Materials in India.Hydrol Current Res.2013; 4(3): 15. doi:10.4172/2157-7587.1000156

Proietti I, Frazzoli C, Mantovani A. Identification and management of toxicological hazards of street foods in developingcountries. Food and Chemical Toxicology 2014; 63: 143152

Vaishnavi C, Singh S, Singh K. Bacterial profile of Dairy products sold in Chandigarh. Tropical gastroenterology: Official Journal of the Digestive Diseases Foundation.2002:23(2):72-75. 